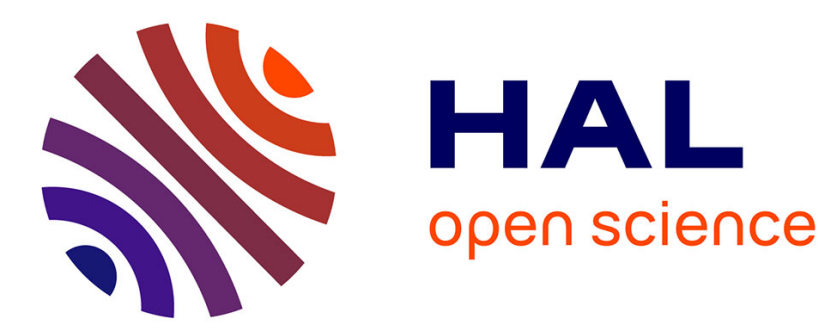

\title{
NO LIMITS TO BORROWING: THE CASE OF BAI AND CHINESE
}

\author{
Yeon-Ju Lee, Laurent Sagart
}

\section{To cite this version:}

Yeon-Ju Lee, Laurent Sagart. NO LIMITS TO BORROWING: THE CASE OF BAI AND CHINESE.

Diachronica, 2008, 25 (3), pp.357-385. 10.1075/dia.25.3.03yeo . hal-00781005

\section{HAL Id: hal-00781005 \\ https://hal.science/hal-00781005}

Submitted on 25 Jan 2013

HAL is a multi-disciplinary open access archive for the deposit and dissemination of scientific research documents, whether they are published or not. The documents may come from teaching and research institutions in France or abroad, or from public or private research centers.
L'archive ouverte pluridisciplinaire HAL, est destinée au dépôt et à la diffusion de documents scientifiques de niveau recherche, publiés ou non, émanant des établissements d'enseignement et de recherche français ou étrangers, des laboratoires publics ou privés. 


\title{
NO LIMITS TO BORROWING: THE CASE OF BAI AND CHINESE
}

\author{
Lee Yeon-Ju (Kangwon National University, Chuncheon, Korea) \\ and \\ Laurent Sagart (Centre de Recherches Linguistiques sur l' Asie Orientale, Paris, France)
}

keywords: Sino-Tibetan, Chinese, Bai, contact, stratification, subgrouping, numerals

\begin{abstract}
Based on the large amount of Chinese-related basic vocabulary in Bai, scholars like Benedict, Starostin and Zhengzhang have claimed a special phylogenetic proximity between Bai and Chinese. In this paper we show that the Chinese vocabulary in Bai is stratified, forming successive layers of borrowings. We identify three such layers, describing the sound correspondences which characterize each of them: two Mandarin layers, one local, one regional for modern words; and an early Chinese layer, acquired during a long and complex period of intimate contact between Bai and Chinese, beginning in Han times and terminating in Late Tang, altogether a millennium or so. This last layer is subdivided into several sublayers. The remaining part of the vocabulary forms the Bai indigenous layer, whose affiliation is clearly Sino-Tibetan, without having any particular proximity to Chinese. In particular, the numerals ' 1 ' and '2' have etymological connections among non-Chinese Sino-Tibetan languages such as Jingpo, Sulung and Tangut. The numerals above "2" are Chinese loanwords and even the numerals " 1 " and "2" have less colloquial variants of Chinese origin. Bai is of interest to comparative linguistics for the extraordinary amount of basic vocabulary it has borrowed from Chinese, all of it during the early period: $47 \%$ of the $100-S w a d e s h$ list.
\end{abstract}

\section{Résumé}

S'appuyant sur l'abondant vocabulaire de base commun au bai et au chinois, des auteurs comme Benedict, Starostin et Zhengzhang ont affirmé qu'il existe une proximité phylogénétique particulière entre ces deux langues. Nous montrons ici que le vocabulaire du bai est stratifié, et qu'il faut y distinguer trois couches chronologiques, dont nous décrivons les correspondances phonétiques avec le chinois. Les deux premières sont formées d'emprunts récents à deux variétés distinctes de mandarin du sud-ouest, l'une locale, l'autre régionale ; la troisième est une couche d'emprunts anciens, acquis au cours d'une longue période de contact d'environ un millénaire, de l'époque Han à la fin des Tang. Cette couche est elle-même subdivisée en plusieurs sous-couches. Le reste du vocabulaire forme la couche indigène : elle est d'affiliation clairement sino-tibétaine, mais sans proximité 
particulière avec le chinois. Notamment, les nombres "1" et "2" peuvent être comparés aux nombres correspondants en Jingpo, Sulung et en Tangoute. Les nombres au-dessus de "2" ont été empruntés au chinois, et même les nombres "1" et "2" ont des variantes littéraires d'origine chinoise. L'intérêt du Bai pour la linguistique comparative tient au nombre exceptionnel de mots du vocabulaire de base empruntés au chinois, depuis les Han jusqu'aux Tang : $47 \%$ de la liste de cent mots de Swadesh.

\section{$\underline{\text { Zusammenfassung }}$}

Aufgrund des umfangreichen, auf der chinesischen Sprache basierenden Grundvokabulars in Bai haben Gelehrte wie Benedict, Starostin und Zhengzhang eine phylogenetische Verwandtschaft zwischen Bai und Chinesisch erkennen wollen. In dieser Arbeit wird gezeigt, dass der chinesische Wortschatz in Bai stratifiziert ist, d. h. er bildet Schichten von Lehnwörtern. Wir haben drei solcher Schichten herausgearbeitet und beschreiben die Lautgesetze, die für jede Schicht charakteristisch sind: zwei Schichten des Mandarin, eine lokale und eine regionale für moderne Wörter, sowie eine ältere chinesische Schicht, die im Laufe einer langen Periode enger Interaktionen zwischen Bai und Chinesisch entstanden ist. Diese Periode begann in der Han-Zeit und endete in der späten Tang-Zeit - das ergibt also eine Zeitspanne von ca. 1000 Jahren. Diese letzte Schicht ist in mehrere Unterschichten aufgeteilt. Der verbleibende Teil des Vokabulars bildet die indigene Baischicht, welche klar dem Sino-Tibetanischen zuzuordnen ist, jedoch ohne irgend eine besondere Verwandtschaft zum Chinesischen aufzuweisen. Insbesondere Nummer 1 und 2 besitzen etymologische Verbindungen zu nichtchinesichen Sprachen wie Jingpo, Sulung oder Tangut. Für vergleichende Sprachwissenschaft ist Bai interessant wegen des außergewöhnlich großen, gänzlich während der frühen Periode aus dem Chinesischen übernommenen Grundvokabulars: $47 \%$ der 100-Worte-Swadesh-Liste.

\section{Introduction}

Bai is a Sino-Tibetan language spoken in Yunnan. Its affiliation within Sino-Tibetan is disputed. The classical view (Li 1937; Dell 1981; Zhao 1982; Lee \& Sagart 1998) is that Bai is a Tibeto-Burman language that has received very strong Chinese influence, especially in its vocabulary. Other scholars (Benedict 1982, Starostin 1995b, Zhengzhang 1999), noting the very large amount of basic vocabulary shared by Chinese and Bai, regard Bai as most closely related with Chinese within Sino-Tibetan (Benedict) or even as an early dialect of 
Chinese (Starostin). For discussions of the history of the Bai language see Bradley (1979), Wiersma $(1990,2003)$.

In many familiar cases of lexical borrowing, loans from a donor language form a single, well identifiable layer- within the recipient. However, when Chinese is the donor to a language with which it has a long history of contact, the situation is different. Chinese culture has experienced over time a succession of periods of expansion and contraction: as shown by Norman (1979), during periods of Chinese cultural expansion ("waves of sinicity"), important numbers of loanwords are issued to languages in contact -including Chinese "dialects". In any given language, then, Chinese loanwords are stratified, forming several distinct chronological layers, each with its specific correspondence rules.

This paper is a study of the stratification of the vocabulary of one dialect of Bai, spoken in Jianchuan 劍川. The data are drawn from Huang et al. (1992, language \#48), a lexical atlas of Sino-Tibetan languages in China. The groundwork for this study was conducted in 19971998 by the authors in Geneva and Paris. A preliminary report was made at a conference in Lund in 1998 (Lee \& Sagart 1998). ${ }^{1}$ Our aim in that paper was, first, to clarify the stratification of Chinese loanwords to Bai, and second, to reassess the question of the affiliation of Bai taking into account the stratification of its lexicon. Our tool for analyzing this stratification was the coherence principle (first explicitly formulated in Sagart \& Xu 2001):

"the initial, rhyme and tone correspondences on a borrowed syllabic morpheme obey the same set of correspondences"

(Sagart \& Xu 2001:15)

This principle states that in borrowed syllabic morphemes, all correspondences come from a single layer or stratum. To those who regard sound change as essentially regular, this is close to a truism. However, especially in China, Hong Kong and Taiwan, some scholars associated with W. S.-Y. Wang's theory of Lexical Diffusion claim that borrowed sounds will compete with other borrowed sounds within the lexicon of the recipient language, in effect creating situations where the correspondences on a borrowed syllabic morpheme come from different layers.

\footnotetext{
1 See http://halshs.archives-ouvertes.fr/halshs-00250200/fr/ .
} 
In the course of analyzing the data, one of us (Lee Yeon-ju) discovered that the principle extended to disyllables too. This led to the formulation of the extended principle of coherence in Sagart and Xu (2001).

"The initial, rhyme and tone correspondences on all syllables of one borrowed polysyllabic morpheme obey the same set of correspondences, provided the morpheme is semantically noncompositional"

(Sagart \& Xu 2001:16)

This means that in borrowed disyllabic words, both syllables belong to the same layer. Semantic noncompositionality was selected as a protection against hybrid forms, i.e. compound words with morphemes drawn from different borrowing layers. Such hybrid forms were not borrowed as units, but were assembled within Bai from morphemes borrowed at different periods. There are many such examples in Bai. An example is 'fist' sł33 tढhuẽ55 where the first syllable, from Chinese 手 'hand', MC *syuwX, belongs to our early layer, while the second, from Chinese 拳 'fist' (Mandarin t6hyan35), is a Mandarin loanword. However, the great majority of borrowed disyllables in Bai are from a disyllabic Chinese word and the extended principle of coherence applies. This principle is a very powerful tool for working out the stratification of Chinese loanwords in a language like Bai, because each borrowed disyllable presents us simultaneously with two correspondences of syllable onsets, two correspondences of rimes and two correspondences of tones, all from the same layer. Tones are particularly useful for the purpose of discriminating between layers. In most cases, twotone combinations are distinctive enough to permit correct layer assignment, even in the case of varieties of southwestern Mandarin which are mutually perfectly intelligible, as we show below.

The present study is our final report on our work. It is based on our analysis of Bai disyllables, and it relies principally on the extended principle of coherence.

Bai syllables are $C\left(G_{1}\right) \vee\left(G_{2}\right)$ (where 'G' stands for a nonsyllabic high vowel) in structure. Vowels are either tense or lax, and either oral or nasal. For an outline of Jianchuan Bai phonology, see Huang et al. (1992: 675-676, hereafter TBL; Xu and Zhao 1984 for a slightly different account). Here we limit ourselves to reproducing tables of initials consonants and tones from Huang et al.-

Bai initial consonants 


\begin{tabular}{|l|l|l|l|l|}
\hline $\mathrm{P}$ & ts & $\mathrm{t}$ & $\mathrm{t} 6$ & $\mathrm{k}$ \\
\hline $\mathrm{Ph}$ & tsh & th & t6h & kh \\
\hline $\mathrm{M}$ & & $\mathrm{n}$ & $\mathrm{n}$ & $\mathrm{\eta}$ \\
\hline $\mathrm{F}$ & $\mathrm{s}$ & & 6 & $\mathrm{x}$ \\
\hline $\mathrm{V}$ & $\mathrm{z}$ & & & $\mathrm{\gamma}$ \\
\hline & & $\mathrm{I}$ & $\mathrm{j}$ & \\
\hline
\end{tabular}

Note: $p t k$ ts t6 are voiced when occurring with tones 33 and 21

Bai tones

$\begin{array}{lllll}55 & 42 & 35 & 33 & 21^{2}\end{array}$

Notes:

- Bai tone 35 occurs only in recent Chinese loanwords in the Entering tone. See Table 3 for examples.

- 42 has 'mixed creaky phonation' (聲門混合擠擦音), 21 has breathiness (氣化現象)

- All tones are compatible with lax vowels.

- Only tones 55, 33 and 21 are compatible with tense vowels.

Before we proceed to give a description of each layer of loanwords to Bai, we provide here some background on Chinese. Efforts to reconstruct Chinese have concentrated mainly on two periods: Middle Chinese (MC), a pronunciation system for Chinese characters embodied in the Qie Yun, a dictionary published in 601 C.E., which has good sound correspondences to modern dialects except Min; and Old Chinese (OC), the educated standard of China around 500 B.C.E. MC pronunciation is reconstructed by fleshing out the phonemic categories in the Qie Yun with sound values that can be regarded as ancestral to their reflexes in modern dialects. Although reference to modern dialects here is reminiscent of the comparative method, the MC categories are not derived through the comparative method. If the comparative method were applied to modern Chinese dialects, the result would presumably be a phonological system older than MC by several centuries. Such a system has not been reconstructed, however. The method for reconstructing Old Chinese is even more idiosyncratic: it takes advantage of the existence of two independent, yet convergent, bodies

\footnotetext{
2 This paper uses Y. R. Chao's 5-level tone scale (from 5-high to 1-low). Two digits are used to mark the beginning and endpoint of a tonal contour; thus ' 21 ' means ' a tonal contour going from mid-low to low'.
} 
of information: (a) the rimes in the Book of Odes, and (b) the phonetic element in the Chinese script. The reconstruction of OC morphology relies on internal reconstruction.

The phonological evolution between MC and the modern dialects, especially modern Mandarin, has been abundantly studied. Before proceeding further it is necessary to describe here the evolution of MC tones and manners of articulation into SW Mandarin, a variety of Mandarin spoken in the SW provinces of Guizhou, Sichuan and Yunnan:

\begin{tabular}{|c|c|c|c|c|}
\hline MC tones & \multirow[t]{2}{*}{ Level 平 } & \multirow[t]{2}{*}{ Rising 上 } & \multirow[t]{2}{*}{ Departing 去 } & \multirow[t]{2}{*}{ Entering 入 } \\
\hline$M C$ initials & & & & \\
\hline voiceless unasp. obstruents & $p-1$ & $p-3$ & $p-4$ & $\mathrm{p}-2$ \\
\hline voiceless asp. obstruents & ph-1 & ph-3 & ph-4 & ph-2 \\
\hline voiced obstruents & ph-2 & $p-4$ & $p-4$ & $p-2$ \\
\hline Sonorants & $\mathrm{m}-2$ & $m-3$ & $\mathrm{~m}-4$ & $\mathrm{~m}-2$ \\
\hline
\end{tabular}

Table 1: Reflexes of MC tones and manners of articulation in SW Mandarin, using labials to represent all places of articulation. ' $p-1$ ' in the first cell means that SW Mandarin normally has voiceless unaspirated obstruents in tone 1 corresponding to $\mathrm{MC}$ unaspirated obstruents under the MC Level tone.

We now give an outline description of each of the lexical layers in Bai (a detailed description of their phonological characteristics would require a monograph-size study). We begin with words obviously borrowed from southwestern Mandarin, which form two distinct layers: B1 and B2.

\section{The local Mandarin layer B1}

Judging from Middle Chinese (MC) tones and initial consonants, the disyllabic loans to Bai in this layer give the picture of a typical Mandarin dialect: the MC voiced obstruents have become voiceless aspirated under Level, but voiceless unaspirated under the other tones; the Level tone is split along the MC voicing distinction, the Departing tone is unsplit, and the Rising tone has lost its words with voiced obstruent initials to the Departing tone. What is noteworthy in a Yunnan context are the different reflexes for the MC lower Level and Entering tones, 21 and 35 respectively:

\begin{tabular}{|c|c|c|c|c|}
\hline MC tones & \multirow[t]{2}{*}{ Level 平 } & \multirow[t]{2}{*}{ Rising 上 } & \multirow[t]{2}{*}{ Departing 去 } & \multirow[t]{2}{*}{ Entering 入 } \\
\hline MC initials & & & & \\
\hline voiceless unasp. obstruents & 33 & 21 & $\underline{5} \underline{5}$ & 35 \\
\hline
\end{tabular}




\begin{tabular}{|l|l|l|l|l|}
\hline voiceless asp. Obstruents & 33 & 21 & $\underline{5} \underline{5}$ & 35 \\
\hline voiced obstruents & $\underline{21}$ & $\underline{5} \underline{5}$ & $\underline{5} \underline{5}$ & 35 \\
\hline Sonorants & $\underline{21}$ & 21 & $\underline{5} \underline{5}$ & 35 \\
\hline
\end{tabular}

$\mathrm{T} 0=33$

Table 2: Reflexes of MC tones in B1 disyllabic loans to Bai (the lower tone series is in gray) Jianchuan Mandarin is one of the few Mandarin dialects in Yunnan which maintain a distinction between the Entering and Lower Level tones. Here are the contours of Jianchuan Mandarin tones (based on Wu 1989:118): upper Level = 55, lower Level = 42, Rising = 31, Departing $=45$, Entering $=21 .{ }^{3}$ Tones in Layer B1 and Jianchuan Mandarin are similar, especially for contour, except that the Entering tone is rising in B1. Examples (Table 3):

\begin{tabular}{|c|c|c|c|}
\hline Gloss & & $\begin{array}{l}\text { tones in Jianchuan } \\
\text { Mandarin }{ }^{4}\end{array}$ & Bai \\
\hline mother's brother & 舅舅 & D-D & t $6 \underline{0} 55$ t $6 \underline{0} 55$ \\
\hline beard & 腮䯽 & UL-IL & [lao55] sai33 xü21 \\
\hline crane & 白鶴 & $E-E$ & pa35 xo35 \\
\hline chili & 辣子 & $\mathrm{E}-0$ & la35 tsi33 \\
\hline potato & 洋芼 & IL-D & ña21 jy55 \\
\hline woolen cloth & 毛呢 & IL-IL & mo21 ni21 \\
\hline head-cloth & 包頭 & uL-IL & po33 tho2 11 \\
\hline coral & 珊瑚 & uL-IL & sẽ33 xu21 \\
\hline spoon & 調盖 & IL-uL & thiô21 kə̃33 \\
\hline means & 辦法 & $D-R$ & pãa5 fa35 \\
\hline trivet & 三足 & uL-E & sã33 t6u35 \\
\hline two-stringed violin & 二胡 & D-IL & a 55 xu21 \\
\hline dragon king & 龍王 & IL-IL & no21 uã 21 \\
\hline boundary & 界限 & D-D & ke55 €̊i55 \\
\hline dusk, twilight & 黃昏 & IL-uL & xuã21 xuẽ33 \\
\hline
\end{tabular}

3 The terms 'Level', 'Rising', 'Departing' and 'Entering' are traditional labels for Middle Chinese tone categories. They are without descriptive value in the modern dialects; the terms 'upper' and 'lower' denote their voiceless-initial and voiced-initial subsets, respectively.

4 Jianchuan Mandarin tone categories are here marked as: $\mathrm{LL}=$ upper Level, IL = lower Level, $\mathrm{R}=$ Rising, $\mathrm{D}=$ Departing, $\mathrm{E}=$ Entering, 0 = light tone (toneless syllable). A label such as 'upper Level' indicates a tone category originating in voiceless-initial subset of the Middle Chinese Level tone category. 


\begin{tabular}{|c|c|c|c|}
\hline future & 將來 & UL-IL & tб̃a33 le21 \\
\hline in the beginning & 開始 & uL-R & khe33 sa21 \\
\hline monday & 星期－ & uL-uL-E & 6ə̃33 tçhi33 ji35 \\
\hline tuesday & 星期二 & uL-uL-D & 6ə̃33 tçhi33 â55 \\
\hline honest & 老實 & R-E & lo21 sa35 \\
\hline $\begin{array}{l}\text { arrogant, } \\
\text { conceited }\end{array}$ & 驕傲 & uL-D & t6o33 o55 \\
\hline polite & 客氣 & $E-D$ & kha35 tci55 \\
\hline to keep secret & 保密 & R-E & po21 mi35 \\
\hline to sing a song & 唱歌 & D-uL & tshã55 ko33 \\
\hline to develop & 發展 & E-R & fa35 tsã21 \\
\hline to oppose & 反對 & R-D & fã21 tue 55 \\
\hline $\begin{array}{l}\text { to } \\
\text { assemble/muster }\end{array}$ & 集合 & $E-E$ & tci35 xu35 \\
\hline to pass, go by & 經過 & uL-D & t6ə̃33 kuon55 \\
\hline to queue & 排隊 & IL-D & phâ21 tue 55 \\
\hline to dance & 跳舞 & D-R & thio55 vv21 \\
\hline to prepare & 準備 & R-D & tsuẽ21 pí55 \\
\hline
\end{tabular}

Table 3: Examples of B1 disyllabic words in Jianchuan Bai

This vocabulary is modern, but not very recent in character. One notes the American plants chili and potato, indicative of a Qing dynasty (1644-1911) date of borrowing. The "Cultural Revolution" vocabulary of Jianchuan Bai in Xu and Zhao (1984) is also clearly B1. Thus Jianchuan Mandarin is probably the source of B1 loans, and the period of borrowing extends at least from mid- or late Qing to the 1960s.

Not surprisingly, basic vocabulary items in this layer are very scarce: on a Swadesh-100 list, the only possible instance is 'claw' 爪子 tsua21 tsi33, which fits the B1 correspondences, although it could also belong to layer B2 (see below).

\section{The regional Mandarin layer B2}

The disyllabic loans in this layer point to a 4-tone Mandarin dialect with the same general Mandarin characteristics as B1, but here lower Level and Entering are merged. Absence of a distinction between upper and lower Level is probably not a feature of the source dialect, but the result of the impossibility for Bai speakers to reproduce the distinction using native Bai tones. 


\begin{tabular}{|l|c|c|c|c|}
\hline MC tones & Level 平 & Rising 上 & Departing 去 & Entering 入 \\
\cline { 1 - 3 } MC initials & & & & \\
\hline voiceless unasp. obstruents & 55 & 21 & $\underline{33}$ & 55 \\
\hline voiceless asp. obstruents & 55 & 21 & $\underline{33}$ & 55 \\
\hline voiced obstruents & 55 & $\underline{33}$ & $\underline{33}$ & 55 \\
\hline sonorants & 55 & 21 & $\underline{33}$ & 55 \\
\hline
\end{tabular}

$\mathrm{T} 0=33$ after 55,21 after 33

Table 4: Reflexes of MC tones in B2 disyllabic loans to Bai (the lower tone series is in gray)

Yunnan Mandarin 4-tone systems are fairly stereotyped from the point of view of contours.

The tones in the provincial capital Kunming 昆明 (Wu et al. 1989: 114) and in Heqing 鶴慶, a county prefecture adjoining Jianchuan in the East (Wu et al. 1989:118), are identical: Upper Level $=44$, Lower Level, Entering $=31$, Rising $=53$, Departing $=213$. That is the most standard type of tone system for Yunnan Mandarin. We will assume that a slightly different version of this system, in which the Lower Level, Entering category was mid-level 33 rather than mid-to-low falling 31, is the source of the B2 loans. Bai would then naturally have used its highest level tone, 55, to render the donor language's highest level tone, 44; it would have used its non-creaky falling tone, 21 , to render the donor's only falling 53 tone; having no dipping tone of its own, it would have rendered the donor's 213 using its mid-level tone, 33. Finally, Bai would have been unable to distinguish between the donor's level tones, 44 and 33 , treating them both as 55 .

Examples:

\begin{tabular}{|l|l|l|l|}
\hline Gloss & & Yunnan Mandarin & Bai \\
\hline Steam & 蒸汽 & uL-D & tsə̃55 t6hij33 \\
\hline Sulfur & 硫磺 & IL/E-uL & lio55 xuã55 \\
\hline business & 生意 & UL-D & sə̃55 jii33 \\
\hline Friend & 朋友 & IL/E-R & phə̃55 jo21 \\
\hline Buddhist nun & 尼姑 & IL/E-uL & ni55 ku55 \\
\hline Aunt & 姨姨 & IL/E-IL/E & ji55 ji55 \\
\hline Yak & 绠牛 & IL/E-IL/E & ma55 nio55 \\
\hline grape & 葡萄 & IL/E-IL/E & phu55 tho55 \\
\hline
\end{tabular}

5 General Yunnan Mandarin tones are here marked as in Table 3 above, with the difference that the merged lower Level + Entering category is marked as IL/E. 


\begin{tabular}{|c|c|c|c|}
\hline banana & 芭蕉 & uL-uL & pa55 t6055 \\
\hline tangerine & 桔子 & E-0 & t6u55 tsi33 \\
\hline cotton & 棉花 & IL/E-uL & mi55 xua55 \\
\hline butter & 酥油 & UL-IL/E & su55 jo55 \\
\hline satin fabric & 緞子 & D-0 & tuã33 tsi21 \\
\hline hat & 帽子 & $D-0$ & mo33 tsi21 \\
\hline socks & 襪子 & E-0 & va55 tsi33 \\
\hline boots & 靴子 & uL-0 & 6ue55 tsi33 \\
\hline treasured & 寶貝 & $\mathrm{R}-0$ & po21 pê33 \\
\hline stool, bench & 板登 & R-D & pá21 tõ55 \\
\hline capital & 本錢 & R- IL/E & pə̃21 tshẽ55 \\
\hline interest & 利息 & D-E & li33 $6 i 55$ \\
\hline scissors & 剪刀 & $R-u L$ & tçi21 ta55 \\
\hline wheel & 輪子 & IL/E-0 & nue55 tsi33 \\
\hline pack rack & 架子 & D-0 & tढa33 tsi21 \\
\hline story & 故事 & D-D & kun33 sij33 \\
\hline joke & 笑話 & D-D & 6ㅇ33 xuạ33 \\
\hline fortune, luck & 運氣 & D-D & nue 33 tchhi33 \\
\hline temper, character & 脾氣 & IL/E-D & phi55 tढ̣i33 \\
\hline mark, sign & 記號 & D-D & teij33 xo33 \\
\hline color & 顔色 & IL/E- IL/E & ni55 sa55 \\
\hline zero & 零 & IL/E & ni55 \\
\hline cheap & 便宜 & IL/E- IL/E & phi55 ji33 \\
\hline pleasantly cool & 清涼 & uL-IL/E & tçhə̃55 nia55 \\
\hline honest & 規矩 & uL-R & kue55 tcy21 \\
\hline careful & 細心 & D-uL & ६i33 ๔ə̃55 \\
\hline happy and excited & 喜歡 & R-uL & ఢi21 xuã55 \\
\hline safe & 平安 & IL/E-uL & phiã55 na55 \\
\hline affectionate & 親熱 & uL-E & tçhə̃55 za55 \\
\hline clear up (liquid) & 澄清 & IL/E-uL & tõ 33 tçhã55 \\
\hline transmit (to posterity) & 傳代 & IL/E-D & tshuẽ55 tê33 \\
\hline promise, consent & 答應 & E-uL & ta55 nəِ33 \\
\hline divide family & 分家 & uL-uL & fã55 tca55 \\
\hline separate & 分開 & uL-uL & fã55 khe55 \\
\hline complain to superior & 告狀 & $D-D$ & kô33 tsuãa33 \\
\hline
\end{tabular}




\begin{tabular}{|c|c|c|c|}
\hline assess, estimate & 估計 & uL-D & ku21 tढ̣i33 \\
\hline shy & 含羞 & IL/E-uL & xã55 su55 \\
\hline to regret & 懊悔 & D-R & on33 xue21 \\
\hline to doubt & 疑心 & IL/E-uL & ni55 ๔ə̃55 \\
\hline drive car & 開車 & uL-uL & khe55 tshe55 \\
\hline $\begin{array}{l}\text { consult, discuss, } \\
\text { negotiate }\end{array}$ & 商量 & UL- IL/E & sã55 niã55 \\
\hline notify, inform & 通知 & uL-uL & thõ55 tsa55 \\
\hline want & 想要 & R-D & бa21 no33 \\
\hline digest & 消化 & uL-D & 6055 xuạ33 \\
\hline fight, vie for & 爭搶 & uL-R & tsə̃55 t6hã21 \\
\hline turn a corner & 轉弯 & R-uL & tsuễ21 nũe55 \\
\hline mule & 騾子 & IL/E-0 & lo55 tsi33 \\
\hline donkey & 驢子 & IL/E-0 & li55 tsi33 \\
\hline centipede & 蜈蚣 & IL/E-uL & ᄁo55 kõ55 \\
\hline
\end{tabular}

\section{Table 5: Examples of B2 loans to Bai}

B2 loans are about twice as numerous as B1 loans on our data. They are slightly more modern and urban in character: butter; scissors; drive car; capital (financial term); interest; clothes; there are fruit names (banana, grape, tangerine) and domesticated animal names (donkey; mule) but no plant names. We conjecture that the source of B2 loans is 'standard' Yunnan Mandarin, perhaps as spoken in Jianchuan county prefecture.

Basic vocabulary items in this layer are no more numerous than in B1: aside from 'claw', already mentioned, no Bai item in a Swadesh-100 list fits the B2 correspondences.

\section{The early Chinese layer A.}

We regard this layer as entirely borrowed from Chinese, like B1 and B2. This view will be justified in the rest of this paper. The disyllabic loans in this layer point to a non-Mandarin donor: the MC voiced stops are represented by unaspirated stops under each MC tone; the Level and Entering tones are only partially split; the Rising tone is unsplit; part of the Departing tone is represented by a separate tone; another part of it is identical with pre-split Entering.

\begin{tabular}{|l|l|l|l|l|}
\hline MC tones & Level 平 & Rising 上 & Departing 去 & Entering 入 \\
\cline { 1 - 2 } MC initials & & & & \\
\hline
\end{tabular}




\begin{tabular}{|l|c|c|c|c|}
\hline voiceless unasp. obstruents & 55 & 33 & 21 (some $\underline{33}$ ) & $\underline{3} \underline{3}$ \\
\hline voiceless asp. obstruents & 55 & 33 & 21 (some $\underline{33}$ ) & $\underline{3} \underline{3}$ \\
\hline voiced obstruents & 42 (some 55) & 33 & 21 (some $\underline{33}$ ) & $\underline{3} \underline{3}, \underline{2} 1$ \\
\hline sonorants & 42 (some 55$)$ & 33 & 21 (some $\underline{3}$ ) & $\underline{3} \underline{3}, \underline{2} 1$ \\
\hline
\end{tabular}

T0 $=55$ (word-initially, ex.: 'tadpole'), word-finally 33

Table 6: Reflexes of MC tones in layer A disyllabic loans to Bai (the lower tone series is in gray).

In our original conference paper (see fn. 1) we gave full correspondences for initial consonants and rimes for this layer. However, as far as words of two syllables or more are concerned, in practice tone and initial consonant correspondences are enough for assignment to one or the other of our three layers.

In the table below, we give examples of layer A di- and polysyllables. Although layer assignment in monosyllables is more hazardous than in longer forms, we have added monosyllabic morphemes belonging to closed sets, such as the four seasons, the twelveyear cycle etc., when the entire set shows layer-A correspondences. In such cases the principle of extended coherence applies to the closed set paradigm instead of to a disyllabic morpheme.

\begin{tabular}{|l|l|l|l|}
\hline Gloss & & Middle Chinese & Bai \\
\hline light & 日照 & IE-uD & ni33 tso33 \\
\hline moon & 明月 & IL-IE & mi55 nuá33 \\
\hline weather & 天日 & uL-IE & xẽ55 ni33 \\
\hline thunder & 天鳴 & UL-IL & xẽ55 ma42 \\
\hline sea & 大湖 & ID-IL & to21 ko42 \\
\hline dry fields & 田地 & IL-ID & xẽ55 tci21 \\
\hline paddy fields & 水地 & uR-ID & 6y33 tci21 \\
\hline sand & 沙子 & UL-0 & so55 tsi33 \\
\hline wave & 波浪 & uL-ID & po55 no42 \\
\hline household & 人間 & IL-uL & ni42 kã55 \\
\hline eyebrow & 眼眉 & IR-IL & nue33 mi55 \\
\hline ear & 耳頭 & IR-IL & ni33 tiə42 [kuã55] \\
\hline thigh & 股頭 & uR-IL & kua33 tiə42 [kä33] \\
\hline
\end{tabular}

6 Historical tone categories are marked as uL 'upper Level', IL 'lower Level', uR 'upper Rising', IR 'lower Rising', uD 'upper Departing', ID 'lower Departing', uE 'upper Entering', IE 'lower Entering'. 


\begin{tabular}{|c|c|c|c|}
\hline calf of leg & 細腳 & uD-uE & se21 kon33 \\
\hline elbow & 手肘子肘 & uR-uR-uR-uR & $\begin{array}{l}\text { si33 ts } 33 \text { tsi33 } \\
\text { ts } \underline{3} 33\end{array}$ \\
\hline finger & 手指 & uR-uR & si33 tsa33 \\
\hline thumb & 手頭拇 & uR-IL-IR & si33 tiə42 mo33 \\
\hline middle finger & 中手頭指 & uL-uR-IL-uR & $\begin{array}{l}\text { tsõ42 si33 tiə42 } \\
\text { tsa33 }\end{array}$ \\
\hline brain & 腦髓 & IR-uR & no33 су33 \\
\hline bone & 骨頭 & uE-IL & kuạ33 tiə42 \\
\hline joint & 手節腳節 & uR-uE-uE-uE & $\begin{array}{l}\text { si33 tse } 33 \text { ko } 33 \\
\text { tse } 33\end{array}$ \\
\hline uvula & 細舌 & UD-IE & se21 tse 21 \\
\hline common people & 百姓 & $u E-u D$ & pạ33 6a्ã21 \\
\hline doctor & 葯生 & IE-uL & jọ33 sã55 \\
\hline carpenter & 木匠 & IE-ID & ㄲo33 tढõ21 \\
\hline blacksmith & 鐵匠 & UE-ID & the 33 tढ므21 \\
\hline beggar & 要餐飯 & uD-uL-ID & $\begin{array}{l}\text { no33 tsã55 pẽ33 } \\
\text { [xo33] }\end{array}$ \\
\hline lame [person] & 腳缺 & uE-uE & kon33 khe 33 \\
\hline son-in-law & 女婿 & IR-uD & nə33 sô21 \\
\hline grandson & 子孫 & uR-uL & tsi33 suã 55 \\
\hline buffalo & 水牛 & UR-IL & су33 пә42 \\
\hline calf & 細牛 & uD-IL & se21 пә42 \\
\hline pony & 馬駒子頭 & IR-uL-uR-IL & $\begin{array}{l}\text { ma33 t6y33 tsi33 } \\
\text { tiə42 }\end{array}$ \\
\hline lamb & 細羊子 & uD-IL-uR & se21 no42 tsi33 \\
\hline dog & 犬 & $\mathrm{uR}$ & khuã33 \\
\hline deer & 大鹿 & ID-IE & tô33 vư33 \\
\hline yellow weasel & 鼠狼 & uR-IL & su33 lo42 \\
\hline sparrow & 雀子 & uE-0 & tso-33 tsi33 \\
\hline crow & 黑烏 & uE-uL & xㅁ33 o55 \\
\hline tadpole & 蝌蚪 & uL-uR & ku55 tiə33 \\
\hline nit & 白闽 & IE-uE & pạ21 фii33 \\
\hline silkworm & 䖯子 & $\mathrm{IL}-0$ & zã42 tsi33 \\
\hline poplar & 水柳 & uR-IR & бу33 уә33 \\
\hline
\end{tabular}




\begin{tabular}{|c|c|c|c|}
\hline cypress & 松柏樹 & uL-uE-ID & 6õ55 pâ33 tsi21 \\
\hline foodstuff, grain & 五穀 & IR-uE & no33 ko33 \\
\hline awn of wheat & 麥芒子 & IE-IL-0 & mə333 mo55 tsi33 \\
\hline millet & 細白米子 & uD-IE-IR-0 & $\begin{array}{l}\text { se21 pâ21 me33 } \\
\text { tsi33 }\end{array}$ \\
\hline soya bean & 白豆 & IE-ID & pạ21 tiə21 \\
\hline powdered sugar & 砂糖 & UL-IL & so55 to42 \\
\hline soup & 湯 & $\mathrm{uL}$ & xã55 \\
\hline wheat bran & 麥皮子 & IE-IL-0 & mə333 pe42 tsi33 \\
\hline pillow & 枕頭 & uR-IL & tsã33 tiə42 \\
\hline flight of steps & 階臺 & UL-IL & ka55 tiə42 [pã42] \\
\hline mirror & 鏡面 & UD-ID & kâ21 mí21 \\
\hline coal & 火炭 & uR-uD & xue33 thã21 \\
\hline dye & 染料 & IR-ID & zẽ33 lion33 \\
\hline frying wok & 炒菜 & uR-uD & $\begin{array}{l}\text { tshu33 tshi21 } \\
\text { [tshã55] }\end{array}$ \\
\hline fire tongs & 火鉗 & uR-IL & xue33 tci42 [pą21] \\
\hline section of bambo & 竹筒 & UE-IL & tso33 thõ55 \\
\hline saddle & 馬鞍 & IR-uL & ma33 ã55 \\
\hline girth & 馬肚帶 & IR-IR-uD & ma33 tu33 te 33 \\
\hline manger & 馬槽 & IR-IL & ma33 tsu42 \\
\hline reins & 牽馬 & uL-IR & $\begin{array}{l}\text { khẽ55 ma33 } \\
\text { [sõ33] }\end{array}$ \\
\hline $\begin{array}{l}\text { carpenter's ink } \\
\text { marker }\end{array}$ & 墨斗 & IE-uR & mə̣33 tiə33 \\
\hline sieve, sifter & 籮頭 & IL-IL & lo42 tiə42 \\
\hline gunpowder & 火藥子 & UR-IE-0 & xue33 jo33 tsi33 \\
\hline trap & 坑眼 & uL-IR & khuã21 pue33 \\
\hline character, word & 書字 & uL-ID & si55 tsi21 \\
\hline book & 書冊 & uL-uE & si55 tshuaa33 \\
\hline $\begin{array}{l}\text { dragon king (god } \\
\text { of rain) }\end{array}$ & 龍王 & IL-IL & no42 uã55 \\
\hline Buddha & 佛 & IE & ve 21 \\
\hline physical strength & 氣力 & uD-IE & tchhi33 yə21 \\
\hline
\end{tabular}




\begin{tabular}{|c|c|c|c|}
\hline birth day & 生日 & UL-IE & sə̃55 za21 \\
\hline age & 日嵗 & IE-uD & ni33 suá33 \\
\hline danger & 危險 & uL-uR & ue55 cĩ21 \\
\hline use & 用處 & ID-uR & กõ21 tshu21 \\
\hline east & 東 & $\mathrm{uL}$ & tõ55 \\
\hline south & 南 & IL & na42 \\
\hline west & 西 & $\mathrm{uL}$ & sẽ55 \\
\hline north & 北 & $\mathrm{uE}$ & $p \supseteq \underline{33}$ \\
\hline lower part of & 下面 & IR-ID & ya33 mi21 [no33] \\
\hline under the sky & 天下 & uL-IR & хе̃55 уа33 \\
\hline tomorrow & 明日 & IL-IE & mẽ55 nيi33 \\
\hline midnight & 半夜 & UD-ID & pãa21 jo21 \\
\hline rat (year) & 鼠 & uR & su33 \\
\hline ox (year) & 牛 & IL & пә42 \\
\hline dragon (year) & 龍 & IL & no42 \\
\hline horse (year) & 馬 & IR & ma33 \\
\hline ram (year) & 羊 & IL & no42 \\
\hline monkey (year) & 猴猻 & IL-uL & no42 suã55 \\
\hline chicken (year) & 雞 & uL & ke55 \\
\hline dog (year) & 犬 & $\mathrm{uR}$ & kuã33 \\
\hline next year & 後歲 & IR-uD & yə33 sug 33 \\
\hline spring & 二三月 & ID-uL-IE & za21 sã55 nua 33 \\
\hline summer & 夏月 & ID-IE & yo21 nuạ33 \\
\hline autumn & 秋月 & UL-IE & t6hə55 guqu33 \\
\hline winter & 冬月 & UL-IE & tõ55 puạ33 \\
\hline new year's day & 新歲 & uL-uD & 6i55 suạ33 \\
\hline 1 & - & $\mathrm{uE}$ & јi33 \\
\hline 3 & $\equiv$ & $\mathrm{uL}$ & sã55 \\
\hline 4 & 四 & $\mathrm{uD}$ & 6i33 \\
\hline 5 & 五 & $\mathrm{uR}$ & no33 \\
\hline 6 & 六 & $\mathrm{IE}$ & fü33 \\
\hline 7 & $t$ & $\mathrm{uE}$ & tढi33 \\
\hline 8 & 八 & $\mathrm{uE}$ & piqu33 \\
\hline 9 & 九 & $\mathrm{uR}$ & tढə33 \\
\hline 10 & + & IE & tsa21 \\
\hline
\end{tabular}




\begin{tabular}{|c|c|c|c|}
\hline 100 & 百 & IE & pạ33 \\
\hline 1,000 & $千$ & $\mathrm{uL}$ & tढ̆ĩ55 \\
\hline 10,000 & 万 & ID & puạ21 \\
\hline ordinal marker & 第 & ID & $\mathrm{ti} 21$ \\
\hline spacious & 空寬 & uL-uL & khõ55 khuạ33 \\
\hline narrow & 窄狹 & UE-IE & tsạ33 kạ21 \\
\hline square & 四面四角 & uD-ID-uD-uE & $\begin{array}{l}\text { ६i33 mi21 єi33 } \\
\text { kọ33 }\end{array}$ \\
\hline expensive & 價大 & uD-ID & ką21 tọ21 \\
\hline young & 日歲細 & IE-uD-uD & nيi33 suạ33 se21 \\
\hline clean & 乾淨 & uL-ID & kã55 tढə̃21 \\
\hline near, close & 隔近 & uE-IR & kạ33 tс̣ї3 \\
\hline worship & 拜佛 & uD-IE & pạ21 vê21 \\
\hline punch hole & 穿眼 & uL-IR & tshuẽ55 nue33 \\
\hline pierce through & 戳破 & IE-uD & tchâ33 pho21 \\
\hline $\begin{array}{l}\text { to hammer in a } \\
\text { nail }\end{array}$ & 釘釘 & uD-uL & tढ̃a21 tढã55 \\
\hline to hide oneself & 避藏起 & ID-IL-uR & pia33 tsõ42 khə33 \\
\hline have a fever & 發熱 & UE-IE & fá33 nيi33 \\
\hline worry, be anxious & 惡心惡肝 & uE-uL-uE-uL & $\begin{array}{l}\text { ô33 6ĩ55 ô33 } \\
\text { kã55 }\end{array}$ \\
\hline set on fire & 种火 & uD-uR & tsõ̃21 xue33 \\
\hline $\begin{array}{l}\text { to mix powder with } \\
\text { water }\end{array}$ & 和泥 & IL-IL & yo21 ni42 \\
\hline avoid certain foods & 忌嘴(1411) & ID-uR & tढ̣i33 t6y33 \\
\hline $\begin{array}{l}\text { immerse, } \\
\text { submerge }\end{array}$ & 浸入(1446) & uD-IE & tढิ21 nيi33 \\
\hline chop down (tree) & 剒樹 & uE-ID & tso-33 tsi21 \\
\hline Understand & 明白 & IL-IE & ma42 pa21 \\
\hline Solidify & 凝起 & IL-uR & рə42 khə33 \\
\hline $\begin{array}{l}\text { have shot (the } \\
\text { target) }\end{array}$ & 中得 & uD-uE & 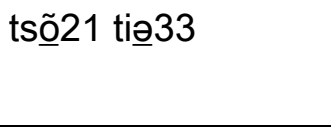 \\
\hline to grow & 高大 & uL-ID & ko55 to21 \\
\hline to rust & [ ] 鐵銹 & uE-uD & [ta42] the 33 sa33 \\
\hline to rise, go up & 升起 & uL-uR & sə̃55 khə33 \\
\hline
\end{tabular}




\begin{tabular}{|c|c|c|c|}
\hline put in order & 收拾 & uL-IE & si55 sâ33 \\
\hline get dark & 天暝 & UL-IL & xẽ55 mia42 \\
\hline Hear & 听得 & uL-uE & tchhã55 tiəo33 \\
\hline $\begin{array}{l}\text { refuse by making } \\
\text { excuses }\end{array}$ & 推託 & uL-uE & thue55 thua 33 \\
\hline be careful & 細心 & uD-uL & se21 6ĩ55 \\
\hline welcome, greet & 迎接 & IL-uE & pa42 tढa33 \\
\hline increase, gain & 加起 & uL-uR & t6a55 khə33 \\
\hline
\end{tabular}

Table 7: Examples of A-layer loans to Bai

Phonological characteristics of the A layer

\section{Instability of correspondences over a long period of continuous borrowing}

We define a layer of loanwords as the set of all the loanwords borrowed in the course of a continuous contact period, however long, between two languages. In the case of relatively short contact periods with intense borrowing, neither language normally has time to change significantly, resulting in compact layers with neatly statable rules of correspondence. Layers B1 and B2 are good examples. In the case of long contact periods, however, although one expects to see some continuity and stability in the sound correspondences, it is normal for both the languages involved in the contact relationship to undergo substantial phonological change during the course of the contact period. As a result the sound correspondences will change over time within the layer, defining a succession of sublayers. Typically, however, the boundaries between these sublayers cannot be drawn neatly, because the sound changes in both the donor and recipient languages will not be synchronized, and the more changes are taken into consideration when working out sublayers, the more complex and elusive the stratification becomes. Yet some aspects of the chronology of changes can often be recovered (see below).

Layer $\mathrm{A}$ is a good example of a layer of borrowings acquired over a long contact period, with complex sound correspondences evolving over time. There is an element of continuity in the correspondences (thus, for tones: upper level 55; Rising 33; upper Entering $3 \underline{3}$ throughout): but this layer has more unstable correspondences than the two Mandarin layers, with variation between tones, initial consonants and rhymes. This can be illustrated by the triplet for 二 'two': ne33, ni21, za21: these three forms are all part of layer A in our analysis (there is also a reading in layer B1: a 55 , in 'Tuesday' and 'two-stringed violin'). From a phonological 
standpoint, the sequence ne $33>$ ni21> za21 recapitulates the history of the word 'two' from Late Archaic to Late Mediaeval times: ne 33 , with its tense vowel and 33 tone, argues for a source form ending in a voiceless obstruent, perhaps final -s or -ts in the late OC pronunciation of ${ }^{{ }^{*} \mathrm{~b}} \mathrm{ni}[\mathrm{j}, \mathrm{t}]-\mathrm{s} ;{ }^{7}$ ni21 is close to the Middle Chinese pronunciation ${ }^{*} \mathrm{nyijH}$ (Baxter 1992; 'H' indicates the Departing tone); and za21 is close to the Late Middle Chinese pronunciation *ri in Pulleyblank's reconstruction (Pulleyblank 1991), supposing the high front vowel had already been centralized under the influence of the retroflex initial in the donor Chinese dialect. The Bai forms for 'two' are further discussed below (Table 11 and text). Future research may make it possible to better sort out the different sublayers within layer $A$, but for the time being it will be sufficient to show that layer $A$ is at least distinct form the modern layers B1 and B2.

\section{One local Chinese donor or several?}

At first sight the relative instability of correspondences might suggest that our A layer was borrowed not from one local variety of Chinese, but from successive forms of standard Chinese with which Bai was in contact at different periods. However, this would not account for the element of continuity in the representation of the Chinese tones throughout the duration of layer $A$, because the dialect base of successive Chinese standards during the period underwent several important shifts: the continuity can only be explained by supposing a local Chinese dialect whose tone system remained relatively stable during the period of contact, while it was itself becoming stratified through continuous contact with successive varieties of standard Chinese, as is the case with most, if not all, directly observable Chinese dialects.

\section{Dating layer $A$}

Chinese was introduced into Yunnan under the reign of Emperor Wu Di of the Han dynasty, in the late 2 nd century B.C.E. This would presumably have been standard Western Han Chinese, a language of which little is known but which was perhaps based on, or at least influenced by, the speech of the western Han capital Chang'an (present-day Xi'an).

We can use linguistic data to gain an understanding of the upper date for the A layer by reference to events in Chinese phonological history: Old Chinese *l- and *hl- had changed to dental stops $d$ - and th-, or to palatal continuants $j$ - and $\varsigma^{-}$(depending on syllable type), by the

\footnotetext{
${ }_{7}$ Old Chinese reconstructions are cited in the Sagart (1999) system. All reconstructed forms begin with superscript 'a' or 'b', to indicate type A or type B syllables.
} 
end of the 1st century C.E. (Sagart 1999), while Old Chinese * ${ }^{*}$ - did not change to l-, filling the gap left by the first change, until later (Ferlus 2005 argues for a 4th-century C.E. date). We find in Bai no examples of laterals corresponding to OC laterals. In type A syllables, OC words with lateral initials show dental stops reflexes: $\mathrm{t}$ - for $\mathrm{OC}$ *al- as in 'peach' 桃 $t a 42$, 'platform' 臺 tiə42, 'ground' 地 t6i21 (ti > tढ़i through secondary palatalization) and in the ordinal marker 第 ti21; corresponding to OC *ahl- we find th- in 'iron' 鉄 the 33, 'hear' 㯖 tढ़hã55 (thia- > tçha- through secondary palatalization). Another set of words with OC lateral initials has $\mathrm{x}$ - in Bai: 'sky' 天 xẽ55, 'soup' 湯 xã55. The word 'field' 田 xẽ55 shows xcorresponding to *al-, seemingly suggesting that the donor Chinese dialect had *ahl- in this word ( $M C$ den implies $O C$ al-). We will return to the reflexes of $O C$ hl- later. In type $B$ the most common reflex of OC *bl- is j-: 'oil' 油 jə42, 'shake' 搖 ju42. One example shows n-: 'use' 用 תỗ21, reminiscent of the Yao form nlong (tone C2) 'to use' (Theraphan 1993). We have no clear examples of OC *hl- words in type-B words. This pattern of reflexes suggests that the Chinese dialect that Bai first came into contact with had already changed its laterals to other sounds. However it does not necessarily mean that contact began only after the changes *l- > d- and *hl- > th- in late Han (see Sagart 1999: 30-31): it may be that contact began in Western Han with a variety of Chinese which treated *ahl- as X-, and that the absence of examples of other kinds of laterals is accidental.

At the same time we find in Bai forms which represent OC * $r$ - as $\gamma$-: 'strength'力 $\gamma \underline{\partial} 21$, 'come'

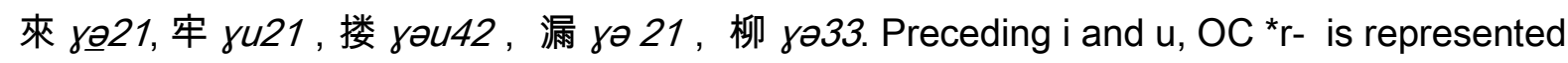
in Bai by j- and v- respectively: 'beneficial' 利 ji21, 'chestnut' 栗 jii21; 'deer' 鹿 vu21; 'dredge for' 掞 vu42. OC *r- is represented as Bai l- in later layers ('old' 老 lu33; 'rite' 禮 li33), as it is in MC and most modern dialects. Thus the first Chinese dialect that Bai borrowed from still had a rhotic for $\mathrm{OC}{ }^{*} r$-: the change to I- had not yet taken place. These two elements, the fate of $O C$ * $\mathrm{I}$ - and ${ }^{*} \mathrm{r}$ - in early loans to Bai, indicate a lower date no later than the 1 st century C.E., when $\mathrm{OC}$ laterals had already changed to their MC values, while $O C{ }^{*} r$ - was still a rhotic. That Bai was already borrowing from Chinese by the end of the Han dynasty is confirmed by the fact that Bai maintains a distinction between $O C$ *-u and *-aw in type $A$, as seen by Starostin (1995b):8 槽 tsu42, 草 tshu33, 撈 vu42, 抱 pu33, 早 tsu33 (<OC *u) vs. 毛 ma42, 高 $k a 55$, 桃 $t a 42$, 刀 $t a 55$, 盜 $\operatorname{ta21}$ (< OC *aw). In Middle Chinese, this distinction is lost, but it was still observed in Eastern Han rhyming (Luo \& Zhou 1958).

\footnotetext{
8 Starostin overinterpreted this retention as a sign of a close genetic relationship between Bai and Chinese.
} 
An approximation for the time at which the A layer ended can be given based on the most innovative features in Chinese phonology to be found in layer A: change of labial stops to labiodental fricatives ('labiodentalization':) 'Buddha' 佛 ve 21, 'belly' 腹 fu33, 'fly' 飛 fa55; change of Shang-tone words with obstruent initials to Departing tone 21: 'house' 戶 $x 021$; 'danger' 危險 Ue55 6i21. These changes are characteristic of Late Middle Chinese as opposed to Early Middle Chinese: they can hardly have entered Bai before mid-Tang (c. 750800 C.E.). This situation testifies to the continuation of Bai-Chinese contacts during the Nanzhao Kingdom years (648-937). We have found no clear signs that linguistic interaction went on during the Dali Kingdom years (938-1253), however.

\section{Other conservative features in the early part of the A layer}

In the preceding section, we established an upper date for the A layer based on conservative features of the early part of that layer: having $x$ - for $O C$ *ahl-; having $\gamma^{-}$, or $\mathrm{V}^{-}$, or $\mathrm{j}$ - (depending on vocalic context) for $\mathrm{OC}$ * $\mathrm{r}$-; and maintaining a distinction between $\mathrm{OC}-\mathrm{u}$ and -aw in type-A syllables. Here we add a few more (a full discussion of phonological stratification with layer $A$ would require a monograph-size study):

- absence of palatal semivowel medial in 'division-3' words. Exx.: 'drink' 飲 ã33, 'bridge' 橋 ku42. Contrast 'lamb' 羊 no42, 'immerse' 浸 t6ĩ21, 'water' 水 $6 y 33$ later in the layer.

Distinguishing the Div.-3 medial from a palatal main vowel is not straightforward, however.

- Lower Level and lower Entering treated as upper Level and upper Entering: 55 and 33. Exx.: 'wheat awn' 麥芒 me33 mo55; 'moon' 明月 mi55 nua33. Contrast 'understand' 明白 ma42 pa21 with distinct lower Level and lower Entering 42 and 21 later in the layer.

- retention of final $-s$ in part of the Departing-tone category, leading to its treatment as

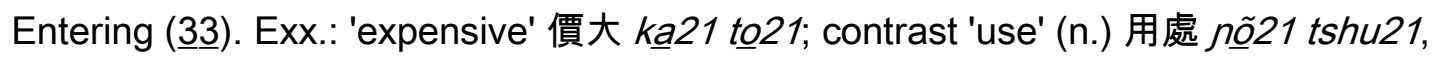
'midnight' 半夜 $p \underline{a} 21$ jo21 later in the layer.

- conservative vocalism:

○ OC *-ə still -ə: 起 khə33.

○ OC *-u still -u: 槽 tsu42, 草 tshu33, 撈 vu42, etc. (above)

We will speak loosely of an early sublayer with conservative features, a late sublayer with innovative features and a middle sublayer where the two types of features overlap. The boundaries between these three sublayers cannot be defined strictly, but we give below (Table 12) a chart of doublets which can illustrate the internal stratification of Chinese loans to Bai, including the internal stratification of the A layer. We think of these three sublayers 
loosely as corresponding to the Han-Wei-Jin, Nanbeichao-early Mediaeval, and late Mediaeval periods respectively.

\section{Characterizing the A-layer donor}

We have argued that the Chinese donor language was a local (Yunnan) variety of Chinese which gradually became stratified through contact with successive varieties of standard Chinese. There are in layer A some interesting phonological features which may serve as clues in characterizing that language.

$$
\text { - *ahl- > x- in 'soup', 'sky' }
$$

The existence in layer $A$ of two reflexes: th- and $x$ - for $O C$ *hl- is interesting. The situation is similar to Middle Chinese, where one has e.g. 隋 'shred sacrificial meat' read as *thwaX and ${ }^{*} x w j i e H$, in GSR 11, a clearly lateral series. In Sagart (1999), the normal MC reflex of OC ${ }^{*}$ ahl- was considered to be th-, while MC x- was treated as OC ${ }^{*}{ }^{*} \mathrm{q}-\mathrm{hl}-$, with * $\mathrm{q}$ - an empty prefix: thus the two readings of 隋 would be reconstructed as *ahloj? vs. ${ }^{*}$ q $q-h l o j(?)-s$. Sagart did not express much confidence in his reconstruction of a q- prefix, however:

\footnotetext{
'The evidence for this prefix is less abundant and varied than for the other prefixes; moreover, its functions have not been established. For this reason, I adopt it tentatively, as a measure making it possible to account for Middle Chinese reflexes while expressing xie-sheng and word-family connections.' (Sagart 1999:116).
}

Another explanation for the duality of reflexes is dialectal: $O C$ *ahl- would be reflected by thin one dialect, and by $x$ - in another. It is well-known that the word 'sky' 天 had two readings in Late Han/Nanbeichao times, one beginning in $x$ - and another in th-. Their geographical distribution was described in Liu Xi's Shi Ming as eastern th- versus western x-, as recognized in Baxter (2005b). Given the geographical location of Bai, it makes sense that the local Han-time Chinese dialect would have pronounced Western features. That Bai does have $x$ - in 'sky' and in two more words with OC laterals where Middle Chinese has th- ('field', 'soup') supports the idea that the evolution of $O C$ *ahl- to MC $\mathrm{x}$ - is a western dialectal feature.

- Reflection of OC -r as -n

Baxter (2005b) identified the reflection of OC -r as another pre-MC phonological feature which shows east-west variation: the evolution was to $-j$ in Shandong and adjoining eastern dialects, while in the center and West the evolution was to $-n$. An example of evolution of $-r$ to -j is in 'west' 西, MC *sej < OC *as-nər (Sagart 2004, there written as *as-nəl). The Western 
equivalent would be *asen. Now the Bai word for 'west' is sẽ55, with nasal vowel, agreeing well with our hypothetical western form *asen. This is another argument in favor of the idea that the local Chinese dialect had a western component.

We now discuss a couple of noteworthy forms:

- 'thigh' 股 kua33 indicates OC *akwa? rather than *aka? (for independent evidence of this see Baxter 2005a; Feng 2005);

- 'middle' 中 tsõ42 (in 'middle finger') with tone 42 (Lower Level) pointing to a voiced initial, while MC *trjuwng and all modern dialects indicate a voiceless initial. Note that 'middle' in 'middle finger' is a stative verb: it is most likely that in the Chinese form underlying the Bai loanword, the voiceless initial, OC *btr-, had been voiced by the intransitive N- prefix (Sagart 2003 for a recent account). Such a form, with Level tone and voiced initial, unknown from modern Chinese dialects and MC lexica, agrees

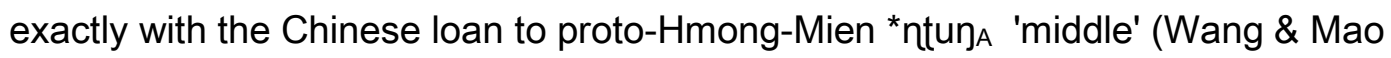
1995), where the nasal prefix is still visible. ${ }^{9}$

\section{A special tone correspondence in layer $A$}

Five tone-A morphemes with sonorant initials in layer A: 'person' 人 ni21, 'wolf' 狼 na21, 'young person' 郎 na 21 , 'shake' 搖 ju21, (animal) pen' 牢 yu21, have tone 21 instead of expected 42 or 55 . The relevant items are listed in Table 8:

\begin{tabular}{|l|l|l|}
\hline Adult & 大人 & to21 ni21 \\
\hline sick person & 病人 & pã21 ni21 \\
\hline Host & 主人 & tsi33 ni21 \\
\hline Others & 人間 & ni21 kã55 \\
\hline shake, quake & 振搖 & ts $\underline{2} 33$ ju21 \\
\hline sheep pen & 羊牢 & no42 yu21 \\
\hline Wolf & 狼 & na21 \\
\hline Girl & 女郎子 & nə33 na21 tsi33 \\
\hline
\end{tabular}

Table 8: Lower Level reflected as 21 in layer $\mathrm{A}$

At least one of these morphemes: 'person' 人, has a segmentally identical variant with the expected 42 contour, in 'household' 人間 ni42 kã55. From the principle of extended coherence, it is clear that these items are part of layer A. Through the principle of coherence, the lower Level=42 feature can be ascribed to a sublayer of $A$ which also reflects $O C{ }^{*} r$ as $\gamma$ -

${ }_{9}^{9}$ The Mienic reflexes shown tone C, probably from an $-s$ suffixed Chinese form. 
('pen'), and yet has developed a palatal medial in division-3 ('human being', 'shake'). The 21 contour could be a variant of the 42 contour of lower Level, but the conditions of variation are not understood.

\section{Lexical characteristics of the A layer}

Loanwords in this layer are most numerous, more than twice as numerous as in layer B2. It contains major lexical paradigms, such as:

- the numerals (though there are non-Chinese colloquial numerals for 'one' and 'two', see below);

- the four directions;

- the four seasons;

- the 12-year cycle.

In addition this layer contains:

- domestic animal names: the dog, cattle, horse;

- horsemanship vocabulary: saddle, girth, reins, manger;

- metal names: silver, copper, iron;

- cultivated plants: rice grain (but not 'paddy'), millet (again, the term indicates that this is a name for the grain, not the plant), wheat, peach, bean;

- wild animal names: the rat, wolf, jackal, fox, deer, yellow weasel;

- Buddhist terms: Buddha, stupa;

- names of artefacts: powdered sugar, gunpowder, vegetable oil, wheat flour, tea, medicine, pillow, bed, flight of steps, mirror, charcoal, chopsticks, plate or dish, cooking stove, lock, glue;

- names of tools: the axe, hammer, rope;

- a term for money.

With domesticated plants one notes the absence of American plants, consistent with an early date of borrowing. Note also that although there are names of domesticated plant and animals in this layer, the names of the rice plant, millet plant and pig, perhaps the most prominent targets of food production in the region are missing.

The term for 'gunpowder' is useful for datation purposes: gunpowder (a mixture of sulphur, saltpeter and charcoal) is believed to have been invented in mid-Tang. Overall the cultural contents of the layer is consistent with a Han to Late-Tang date (approx. 100 C.E. - 900 C.E.), in full agreement with the phonological characteristics of the layer. 
The real surprise with this layer is the sheer amount of basic vocabulary it contains. On a Swadesh-100 list, we find as many as 47 items matching layer A: big 大 to21, long 長 tsõ42, small 細 se21, daughter 女人 nə33 ni21, son 子人 tsi33 ni21, human (n.) 人間 ni21 kã55, dog 犬 khuã33, tree 樹tsi21, seed 種子 tsõ33 tsi33, skin 皮 pe42, bone 骨頭 kua 33 tia42, down, hair 毛 ma42, hair (of head) 頭毛 tia42 ma55, eye 眼 nue33, hand 手 si33, belly 腹 fu33, heart 心 6ĩ55, liver 肝 kã55, drink 飲 ã33, bite 咬 na 33 , hear 㯖得 tढ̆hã55 tiö33, swim 游水 rã42 6y33, come 來 yə35, sit 踞 ku21, speak 說 sua 33 , moon 明月 mi55 nua 33, star 星 6ã55, water 水 6y33, sand 沙子 so55 tsi55, earth 土沙 thu33 sa33, cloud 雲 vã42, smoke 煙子 ni55

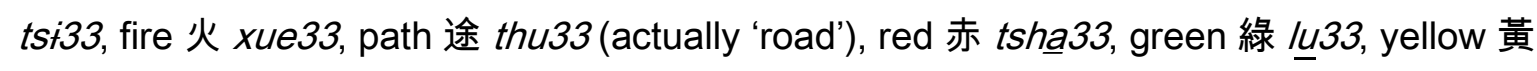
n042, white 白 pa21, black 黑 xə33, midnight 夜 jo21, full 滿 ma33, new 新 6i55, round 圓 pue42, dry 乾 $k \tilde{a} 55$, fly (v.) 飛 fa55, flesh 肌 ka42, die 死 $6 i 33$.

However, two facts must be borne in mind:

- Only a small portion of these items (words like 'skin', 'hair' (of head), 'come', 'sit', 'fire') clearly belong to the early part of layer A; many, like 'big', 'long', 'small', 'woman', 'man', 'human being', 'tree', 'skin', 'feather', 'hand', 'belly' etc., have phonological characteristics indicative of the later part of the layer: even if Bai was most closely related to Chinese, these words could not be shared by Bai and Chinese as a result of common inheritance.

- There is also a sizeable number of non-Chinese, Sino-Tibetan-related basic vocabulary items in Bai, to be examined in the next section.

\section{The Tibeto-Burman layer}

The Bai lexicon contains a non-Chinese, Sino-Tibetan (henceforth 'ST') layer which we call Tibeto-Burman (henceforth 'TB') here for ease of reference, although the existence of a Tibeto-Burman branch of ST needs to be supported by a body of shared innovations. Given the lack of wholly explicit systems of reconstruction for either Tibeto-Burman or Sino-Tibetan (Sagart, 2006), it has not been possible to constrain our study of the TB lexicon in Bai using sound correspondences between Bai and a reconstructed TB or ST pronunciation. In Lee and Sagart (1998), we compared Jianchuan Bai words with Proto-Loloish reconstructions by D. Bradley (1979). We tentatively ascribed Bai words to the TB layer when (a) they could not be related to a Chinese etymon by means of the segmental and tonal correspondences extracted from our study of layers B1, B2 and A, and (b) when they showed some sound correspondences to Bradley's Proto-Loloish. We presented 39 comparisons between Bai and Proto-Loloish. We reproduce the list below, reduced to 25 comparisons (we have removed 
comparisons which we now consider erroneous, or which can with equal plausibility be regarded as Chinese loanwords):

\begin{tabular}{|c|c|c|c|}
\hline gloss & TBL & Proto-Loloish (Bradley) & Bai \\
\hline rain & 10 & ${ }^{*} r-y w a{ }^{1}$ & va33, za33 \\
\hline pig feed & 459 & ${ }^{*} d z a 1$ & tsa33 \\
\hline I & 928 & ${ }^{*} \mathrm{C}$-nga ${ }^{1}$ & no21 \\
\hline thou & 931 & ${ }^{*}$ nang ${ }^{1}$ & no21 \\
\hline $\begin{array}{l}\text { water } \\
\text { (<tears) }\end{array}$ & 158 & ${ }^{*} \mathrm{re}^{1}$ & ji21 \\
\hline this & 942 & *no1 'that' (near) & no21 \\
\hline nose & 80 & ${ }^{*}$ s-na ${ }^{1}$ & ne42 \\
\hline tiger & 304 & ${ }^{*} \mathrm{k}-\mathrm{la}{ }^{2}$ & 1042 \\
\hline sky (<dawn) & 1671 & ${ }^{*} \mathrm{mo}^{2}$ & ma42 \\
\hline $\begin{array}{l}\text { speech, } \\
\text { words }\end{array}$ & 651 & ${ }^{*}$ dang ${ }^{2}$ & tõ42 \\
\hline $\begin{array}{l}\text { head } \\
(<\text { nose })\end{array}$ & 80 & ${ }^{*} u^{2}$ & vu42 \\
\hline earring & 484 & ${ }^{*} \mathrm{k}-$ wang ${ }^{2}$ & kõ42 \\
\hline pine torch & 388 & ${ }^{*} \mathrm{C}-\mathrm{mi}^{2}$ ('fire') & me55 \\
\hline $\begin{array}{l}\text { hard, } \\
\text { laborious }\end{array}$ & 1095 & ${ }^{*} \mathrm{~s}-\mathrm{ra}^{2}$ & so55 \\
\hline urine & 152 & $* \int i^{2}$ & sa55 \\
\hline earth & 40 & ${ }^{*} \mathrm{tsa}^{2}$ & sa33 \\
\hline blood & 129 & ${ }^{*} \mathrm{swe}^{2}$ & suga33 \\
\hline mother & 219 & ${ }^{*} \mathrm{ma}^{3}$ & mo33 \\
\hline to dance & 1677 & ${ }^{*} g a^{3}$ & ko33 \\
\hline eye (<tears) & $79 / 158$ & 'C-myak 'eye' & mi21 \\
\hline expensive & 1054 & ${ }^{*} \mathrm{kak}^{\mathrm{H}}$ & kâ21 \\
\hline untie, undo & 1600 & *k-luat 'free' & luạ33 \\
\hline paddy rice & 403 & ?-gok ${ }^{H}$ & ko42 \\
\hline cold & & 7-grak ${ }^{H}$ & ka42 \\
\hline enough & 1349 & ${ }^{*} \mid \mathrm{lok}^{\mathrm{L}}$ & lu55 \\
\hline
\end{tabular}


One notes terms for 'pig feed' and 'paddy rice', showing this layer originates in a more rural population than layers A, B1 or B2.

On the basis of the comparisons such as those in Table 9 and of sound correspondences we detected in them, we argued that Bai was probably Loloish. In a rejoinder, Matisoff (2001) offered a number of additional comparisons, arguing that when Jianchuan tones are replaced in a general Bai context, including other Bai dialects, the correspondences we detected between Bai and Loloish become less clear. ${ }^{10}$ We will reserve discussion of Bai vs. Loloish for another occasion.

We now identify Bai basic words on a Swadesh-100 list which we regard as being of probable TB origin:

1. I (1sg): no21. This could represent the modern Mandarin 1sg 我 'l' in layer B1, with trivial correspondences, but if so, that would be the only basic word borrowed in that layer. The tone would have to be 33 if it belonged to layer $A$. This word is more plausibly compared to TB nga, PL $C$-nga ' 'l'. If so, it is essentially regular.

2. thou: no21. Irregular vowel and/or tone as a reflex of any of the $n$ - initial Chinese $2 n d$ person pronouns: 汝, 乃 , 爾. Straightforward comparison to PL *nang ${ }^{1}$, compare PL *dang1' 'speech, words', Bai tõ42 'id.'. Nasal vowels are regularly denasalized in Bai after nasal initials.

3. we: ga55. Could be a reflex of 我, a plural pronoun in $\mathrm{OC}$, but vowel correspondence is unparalleled and Bai tone /55/ is irregular corresponding to Chinese Rising tone. Enters into a PL tone-2 correspondence with Wuding $\eta u 11$ and Sani $\eta e 33$ 'id.', therefore the word is clearly ST but probably non Chinese.

4. this. no21. Not a Chinese form. Compare PL *no 'that (near)'.

5. not. a33 ja33. The two forms are variants. Neither is Chinese. With a33, compare the general Jingpo negation a31, and phonetically similar forms of same meaning in Yi (Zhao Yansun 1982: 165).

6. one. a21. A plausible cognate set for this item was proposed by Zhao (1982): Taoping Qiang a31, Aka (= Hruso) $a$, both `one'; Xixia $a$ 'one of a pair'.

7. two. kõ33. The connection to Jingpo la55 khon51 'two' was first pointed out in Zhao (1982). Add Sulung (Tayeng 1990; spoken in NW Arunachal Pradesh, a "central TB"

\footnotetext{
10 In his rejoinder, Matisoff refers to Lee \& Sagart (1998) as "Sagart (1998)".
} 
language according to Bradley's classification) akun, 'second' 11, Rengma (eastern Naga)

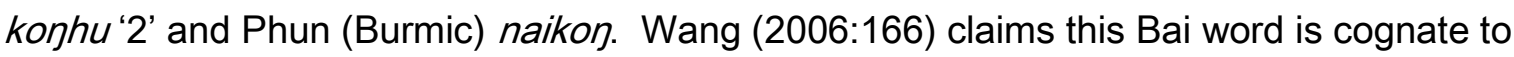
兩 'two', OC *bran?. However he cannot give any evidence that Bai ever had $r$ - and that Chinese ever had k- in this word.

8. blood. sua33. The final and tone correspondences to 血 'blood', MC xwet are regular in the old layer but the initial correspondence is not. Better compared with PL *swe ${ }^{2}$ 'blood'.

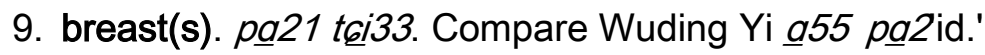

10.walk. pe 33. A Tai origin has been suggested but this is better compared to PL * $p-r e^{2}$ 'run'. 11.rain (n.). za33 va33. za33 should be compared with $\mathrm{PL}{ }^{*} \mathrm{r}$-ywa ${ }^{1}$, and va33 with an unprefixed variant of the same. A comparison with 雨 $\mathrm{MC}$ hjo is feasible for the initial and tone, but Bai /a/corresponding to this Chinese rhyme (and generally to the OC 魚 rhyme category) is unparalleled.

12.mountain. su21. Not a Chinese word (山 MC srean cannot correspond). The word is better compared with Hani $t / v 31$, Naxi dzy21 'id.'.

Although this list is quantitatively limited, it is more basic in character than the list of 47 Chinese-Bai matches on the Swadesh-100 list presented above: it contains in particular three personal pronouns, a demonstrative pronoun, and the lower numerals 'one' and 'two'.

\section{Determining the genetic layer in Bai}

Archaeologists derive relative chronologies of cultural layers based on stratigraphy: older cultural layers are lower in the ground than more recent ones. Are there sites in languages where successive language strata are stratified in an obvious fashion ? we believe the numeral system of a language is one. It is very generally the case that when a language borrows some numerals under ten from another language, the borrowed numerals will form a continuous set beginning with 9 and ending with a lower numeral (such as 9-8-7-6 or 9-8-7-65-4-3). If any indigenous numerals survive, they will form another continuous set below the lowest borrowed numeral (such as 5-4-3-2-1 or 2-1).

In Bai, all numerals above 'two' are Chinese. For 'one' and 'two', however, we find two competing sets: a set of forms of Chinese origin: ji33, ji35 'one' and ni33 'two'; and a set of forms of TB origin: a21 'one' and kõ33 'two' (Table 10).

$\begin{array}{lrr}1 . & j i 33, j i 35 & \text { a21 } \\ 2 . & \text { ni33, ne33 } & \text { kõ33 }\end{array}$

11 We thank F. Jacquesson for bringing the Sulung datum to our attention. 

3.
4.
5.
7. tci33
8. piqu33
9. t6ə33
10. tsâ21

Table 10. Bai numerals of Chinese origin (shaded cells) and of TB origin (clear cells) The numeral ji35 is a B1 loan used exclusively in spelling out numbers in modern contexts such as year names, telephone numbers, codes etc. (Xu \& Zhao 1984: 24sq). In counting things, the Chinese numerals jii3 'one', ne 33 and ni21'two' are limited to numbers above 10: eleven, twelve, twenty, twenty-one, twenty-two, thirty-two, two hundred, etc.; only the TB numerals $a 21$ and $k \tilde{o} 33$ can be used as 'one' and 'two' in counting things. Here are examples drawn from Xu and Zhao (1984:24): ${ }^{12}$

$\begin{array}{lll}\text { jĩ21-kã22 } & \text { a31 } & \text { jĩ21 } \\ \text { person } & \text { one } & \text { CLASSIFIER } \\ \text { "one person" } & & \end{array}$

p乏̃33 kõ33 jo21

board two CLASSIFIER

"two boards"

The Chinese-related numerals cannot be used in this most basic and colloquial function. This shows that the Chinese-related numerals, which belong to layer $A$, are borrowed, and that the TB numerals are inherited. In other words, layer A is borrowed and the TB layer is genetic. This fits well with our observation that the TB layer, although smaller in size than the any of the Chinese layers, is more basic in character.

\section{Summary and conclusion}

We have identified four chronological strata in the Bai lexicon. The genetic layer is SinoTibetan, and clearly non-Chinese. It contains the personal pronouns, the numerals for 'one' and 'two', and other items making up at least $12 \%$ of a Swadesh 100 -word list. The cultural vocabulary ascribable to this layer includes words relating to rice cultivation and the raising of

\footnotetext{
12 Tone values in Xu and Zhao are slightly different from those used in TBL.
} 
pigs. The next layer (layer A) was borrowed from Chinese in a long and complex episode of intimate contact lasting from Han to late Tang. $47 \%$ of a Swadesh 100 -word list, as well as enormous amounts of cultural vocabulary, mostly urban in character, were borrowed from Chinese in the course of that episode. Linguistic interaction between Bai and Chinese appears to have petered out in the first half of the second millennium C.E., to resume in late Ming or Qing times with the introduction of Mandarin to the Chinese southwest. Two distinct layers accommodate recent loans from two varieties of SW Mandarin: Jianchuan Mandarin (B1) and 'regional' SW Mandarin (B2). Almost no basic vocabulary is to be found in these two layers.

Let us illustrate the stratification of the Bai vocabulary using the word 'two' (Table 11) and other examples (Table 12). We believe the three forms of 二 'two' in layer A were borrowed from Chinese at different periods, as part of different lexical items: ne 33 early, as an independent word used in literary contexts and in counting objects above ten; ni21 later on, exclusively in 'twenty' ni21 6i21, which must have displaced an earlier ne 33 tsa21; za21 in the late Middle Chinese period, in expressions like 二三月 za21 sã55 pua33 'spring'; and finally a55 from Jianchuan Mandarin, in words like 'Monday' and 'two-stringed violin' . Note that 二 was never borrowed as an independent word, used for counting objects in twos. In that most basic function, Bai uses kõ33, a non-Chinese form with cognates in Jingpo and other ST languages.

\begin{tabular}{|l|l|l|l|}
\hline layer & Bai & source & use in Bai \\
\hline TB & kõ33 & (genetic) & 'two' \\
\hline$A_{\text {early }}$ & nê33 & late OC ni[jt]s & $\begin{array}{l}\text { cardinal in 'twelve', '(twenty)-two', 'one } \\
\text { hundred and two', etc.; ordinal in 'second'. }\end{array}$ \\
\hline$A_{\text {middle }}$ & ni21 & early MC nyij tone c & in 'twenty' \\
\hline$A_{\text {late }}$ & za21 & late MC nż́t tone c & 'second month' \\
\hline B2 & None & SW Mandarin & \\
\hline B1 & $\underline{a} 55$ & Jianchuan Mandarin & 'Monday', 'huqin' (two-stringed-violin) \\
\hline
\end{tabular}

Table 11: Bai lexical stratification as illustrated by the words for 'two'. Data from Xu \& Zhao (1984:24ff.)

\begin{tabular}{|c|c|c|c|c|c|c|c|c|c|c|}
\hline layer & $=$ & 日 & 大 & 細 & 話 & 毛 & 盤 & 龍 & 分 & + \\
\hline$A_{\text {early }}$ & ne33 & ni33 & & & & & & & \multirow[t]{2}{*}{ pã55 } & \\
\hline$A_{\text {middle }}$ & ni21 & & to221 & se21 & үㅇ21 & $\mathrm{ma} 42$ & pã42 & no42 & & tsạ 21 \\
\hline
\end{tabular}




\begin{tabular}{|l|l|l|l|l|l|l|l|l|l|l|}
\hline A $_{\text {late }}$ & za21 & za21 & & & & & & & & ci21 \\
\hline B2 & & & tạ33 & ci33 & xuạ33 & ma55 & & & fã5 & \\
\hline B1 & â55 & & & & & & phã21 & no21 & & \\
\hline
\end{tabular}

Table 12: More examples of Bai lexical stratification

There, precisely, lies the interest of Bai, a language which has borrowed almost half the words on a Swadesh-100 list from Chinese, while its genetic layer contains less than fifteen matches on the same list. To that extent, Bai is counterevidence to Starostin's claim (1995a: 395) that there are limits to lexical borrowing, specifically that a language cannot borrow more than $15 \%$ of a Swadesh 100 -word list. Starostin argued that once a language has reached that stage, its speakers will shift to the dominant language. Bai shows that this is not the case. The genetic layer in a language cannot be determined mechanistically by looking at the number of matches on a basic vocabulary list.

Bai may be considered one of the world's borrowing champions. How it could borrow so many items from Chinese in the approximately 1000-year period between early Han and Late Tang is not known. Presumably there was intimate contact, widespread bilingualism in Bai cities, probably also high levels of literacy in Chinese, combined with factors favoring the maintenance of Bai in the face of cultural pressure. A contrario, that almost no basic vocabulary was borrowed from Mandarin in the course of 700 years since the Yuan dynasty suggests that present-day generalized Bai-Mandarin bilingualism is recent.

\section{REFERENCES}

Baxter, W. H. III. 2005a. “上古音脂、微两部之间的界限 [the boundary between the Zhi and Wei rhyme categories in Old Chinese]". Power-Point presentation for the First International Symposium on Old Chinese, Shanghai, December 14-18, 2005.

Baxter, W. H. III. 2005b. "Early Chinese dialects". Power-Point presentation for the First International Symposium on Old Chinese, Shanghai, December 14-18, 2005.

Benedict, P.K. 1982. "Chinese and Proto-Tai, part II". Paper presented at the 15th international conference on Sino-Tibetan Languages and Linguistics, Beijing 1982.

Bradley. D. 1979. Proto-Loloish, Scandinavian Institute Monograph Series N39. London and Malmo: Curzon.

Dell, F. 1981 La langue Bai, phonologie et lexique. Paris: Editions de l'Ecole des Hautes Etudes en Sciences Sociales.

Feng, Zheng. 2005. “论上古音鱼 ( 铎 ) 部中模韵系的开合口问题 [On labiality in the Mo rime of the Yu-duo rhyme category]". Paper presented at the First International Symposium on Old Chinese, Shanghai, December 14-18, 2005. 
Ferlus, M. 2005. "L'intérêt linguistique des transcriptions chinoises concernant le Cambodge ancien (Fou-nan et Tchen-la)", 19èmes journées de linguistique Asie Orientale, Paris, 30 Juin-1er Juillet 2005.

Fu, Jingqi and Xu Lin. 2001. "On the origin of seventeen Bai words found in Manshu". Paper presented at the $34^{\text {th }}$ International Conference on Sino-Tibetan languages and linguistics, Kunming, China.

Huang, Bufan et al. 1992. Zang-Mian Yuzu Yuyan Cihui [A Tibeto-Burman Lexicon]. Beijing: Zhongyang Minzu Xueyuan Chubanshe.

Lee, Yeon-Ju and Sagart, Laurent. 1998. "The strata of Bai". Paper presented at the 31st International Conference on Sino-Tibetan Languages and Linguistics. University of Lund, September 30 - October 4, 1998.

Li Fang-kuei. 1937. Languages and dialects of China. The Chinese Yearbook, 1937. Shanghai: Commercial Press.

Li, Shaoni and J. A. Edmondson. 1990. Yunnan Jianchan Baiyu yinzhi he yindiao leixing [Phonetic and Phonological type of Jianchuan Bai of Yunnan]. Zhengyang minzu xueyuan Xuebao 5.

Luo Changpei and Zhou Zumo. 1958. Han-Wei-Jin Nanbeichao Yunbu yanbian yanjiu. [researches on the evolution of rimes in the Han-Wei-Jin and Nanbeichao periods]. Beijing: Kexue Chubanshe.

Matisoff, J.A. 2001. "On the genetic position of Bai within Tibeto- Burman". Paper presented at the $34^{\text {th }}$ International Conference on Sino-Tibetan languages and linguistics, Kunming, China.

Norman, J. 1979. "Chronological strata in the Min dialects". Fangyan 4: 268-274.

Pulleyblank, E. 1991. Lexicon of reconstructed pronunciation in Early Middle Chinese, Late Middle Chinese and Early Mandarin. Vancouver: University of British Columbia Press.

Sagart, L. 1999. The Roots of Old Chinese. Amsterdam: John Benjamins.

Sagart, L. 2004. "The Chinese names of the four directions". Journal of the American Oriental Society, 124, 1: 69-76.

Sagart, L. 2006. "Review of J. A. Matisoff Handbook of Proto-Tibeto-Burman". Diachronica 2006.

Sagart, Laurent \& Xu Shixuan. 2001. "History through loanwords: The loan correspondences between Hani and Chinese", Cahiers de Linguistique-Asie Orientale 30(1):3-54

Starostin, S.A. 1995a. "Comments from Starostin. In: William S.-Y. Wang (ed.) The Ancestry of the Chinese Language". Journal of Chinese Linguistics monograph series no. 8, 393$\underline{404 .}$

Starostin, S.A. 1995b. "The Historical Position of Bai". Moskovskij Lingvisticheskij Zhurnal 1, 174-190.

Sun, Hongkai et al. 1991. Zangmianyu Yuyin he Cihui [Tibeto-Burman phonology and lexicon]. Beijing : Zhongguo Shehui Kexue Chubanshe. 
Tayeng, Aduk. 1990. Sulung language guide. Itanagar: Directorate of Research, Govt. of Arunachal Pradesh.

Theraphan, L.-Thongkum. 1993. "A view on Proto-Mjuenic (Yao)". Mon-Khmer Studies 22: 163-230.

Wang, Feng. 2006. Comparison of languages in contact: the distillation method and the case of Bai. Institute of linguistics, Academia Sinica.

Wang, Fushi and Mao Zongwu. 1995. Miao-yao yu guyin gouni [a reconstruction of the sound system of Proto-Miao-Yao]. Beijing: Zhongguo Shehui Kexue.

Wiersma, Grace. 1990. Investigation of the Bai(Minjia) language along historical lines. UC Berkeley: PhD thesis.

Wiersma, G. 2003. "Yunnan Bai". The Sino-Tibetan languages, ed. by Graham Thurgood \& Randy J. LaPolla: 651-673. London: Routledge.

Wu, Anqi. 2000. "Zangmianyu de fenlei he Baiyu de guishu. [the classification of TibetoBurman and the position of Bai]". Minzuyuwen, 1:1-12. Beijing.

Wu, Jicai et al. 1989. Yunnan Shengzhi. Hanyu Fangyan zhi [A Yunnan province gazetteer]. Section on Chinese dialects. Kunming: Yunnan Renmin Chubanshe.

Xu, Lin \& Zhao Yansun. 1984. Baiyu jianzhi [researches on Bai]. Beijing: Minzu Chubanshe

Zhang, Zengqi. 1990. "Zhongguo xinan minzu kaogu [Archeology on nationalities in Southwestern China]", Yunnansheng bowuguan yanjiu congshu. Kunming : Yunnan Renmin Chubanshe.

Zhao, Yansun. 1982. "Baiyu de xishu wenti [The problem of the genetic relationship of Bai language]", Minzu yuwen yanjïji [collection of studies on Minority linguistics]. 150-188. Xi'ning: Qinghai Minzu Chubanshe.

Zhao, Yansun \& Xu Lin. 1996. Bai-Han cidian [Bai-Chinese dictionary]. Chengdu: Sichuan Minzu Chubanshe.

Zhengzhang, Shangfang. 1999. "Baiyu shi Han-Bai yuzu de yizhi duli de yuyan [The Bai language is an independent branch of the Sino-Bai Family]", Zhongguo yuzhan: Qingzhu Wang Shiyuan jiaoshou liushiwu sui huadan, 19-73. Xianggang: Chengshi Daxue Chubanshe. 